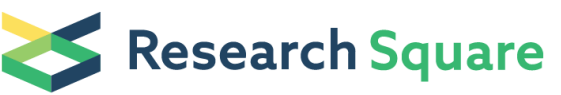 \\ Preprints are preliminary reports that have not undergone peer review. \\ They should not be considered conclusive, used to inform clinical practice, \\ or referenced by the media as validated information.
}

\section{COVID-19 outbreak and Urban dynamics: Regional variations in India}

Devarupa Gupta ( $\nabla$ devarupagupta140890@gmail.com )

International Institute for Population Sciences Govandi Station Road, Deonar, Mumbai: 400088 Maharashtra, India https://orcid.org/0000-0003-

2398-1043

Dibyendu Biswas

Institute of Development Studies Kolkata 27/D, DD Block, Sector 1, Salt Lake, Kolkata: 700064 West Bengal, India

Pintu Kabiraj

Institute of Development Studies Kolkata 27/D, DD Block, Sector 1, Salt Lake, Kolkata: 700064 West Bengal, India

\section{Research Article}

Keywords: COVID-19; urban-centric; cities; modes of transmission; travel networks, spatial regression models

Posted Date: September 29th, 2020

DOI: https://doi.org/10.21203/rs.3.rs-84018/v1

License: (c) (i) This work is licensed under a Creative Commons Attribution 4.0 International License. Read Full License

Version of Record: A version of this preprint was published at GeoJournal on March 3rd, 2021. See the published version at https://doi.org/10.1007/s10708-021-10394-6. 


\section{Abstract}

India was the second highest COVID-19 affected country in the world with 2.1 million cases by $11^{\text {th }}$ August. This study focused on the spatial transmission of the pandemic among the 640 districts in India over time, and aimed to understand the urban-centric nature of the infection. The connectivity context was emphasized that possibly had inflicted the outbreak. Using the modes of transmission data for the available cases, the diffusion of this disease was explained.

Metropolitans contributed three-fourths of total cases from the beginning. The transport networks attributed significantly in transmitting the virus from the urban containment zones. Later, there was a gradual shift of infections from urban to rural areas; however, the numbers kept increasing in the former. The massive reverse migration after lockdown spiked the infected cases further. Districts with airports reported more with influx of international passengers. A profound east-west division in April with higher infections in the southern and western districts existed. By mid-May eastern India saw a steep rise in active cases. Moran's I analysis showed a low autocorrelation initially which increased over time. Hotspot clustering was observed in western Maharashtra, eastern Tamil Nadu, Gujarat and around Kolkata by the second week of August. The diffusion was due to travel, exposure to infected individuals and among the frontline workers. Spatial regression models confirmed that urbanization was positively correlated with higher incidences of infections. Transit mediums, especially rail and aviation were positively associated. These models validated the crucial role of spatial proximity in diffusion of the pandemic.

\section{Introduction}

A rapid urban growth occurring in the latter half of the twentieth century led to an estimated 55.3 percent of the world's population living in urban settlements and expected to hit the 60 percent mark by 2030 (United Nations 2018). About 377.1 million people in India are urban dwellers, comprising of 31.6 percent of the country's total population (Census of India 2011). Increased built-up areas changed interaction patterns between individuals and interfered with previously untouched ecosystems (Neiderud 2015). Anthropogenic environmental changes intimidated human health by creating food and water scarcity, increased natural disasters, displaced populations, and increased infectious diseases (Myers and Patz 2009). A rapid increase in the urban population in the lower latitudes imposed newer risks from microbes and resistant genes to new diseases (Mack et al. 2010). Encroachment into natural habitats and closer proximity to wild animals might have led to the origin of diseases like SARS and COVID-19 (Lee et al. 2020). Intensified and unscientific animal keeping methods have raised the import of earlier unknown pathogens, increasing the exposure to new hosts (Lindahl and Grace 2015). Diseases have re-structured the urban process over centuries, redistributing population over space. Improvements in connectivity posed catalyst for outbreaks like Chagas disease in Latin America, Seoul Hantavirus, SARS, MERS, AIDS, Ebola, and COVID-19. Traditional rural infectious diseases like lymphatic Filariasis, Dengue, Leishmaniasis, West Nile Virus (WNV) infection, etc. adapted to the urban environment, and surveillance of these are difficult (Neiderud 2015).

The emergence of COVID-19 caused by the novel coronavirus, SARS-CoV-2 in the Wuhan city of Hubei, China in early December 2019, took a form of the global pandemic in the next few months. As declared by the World Health Organization (WHO), an international public health emergency, it affected over 213 countries and over 26 million people globally (5 September 2020). The first report in India was on 30 January 2020, a student who returned from Wuhan to Thrissur, Kerala. The first fatality in the country was in Karnataka on 11March with a travel history from Saudi Arabia. As an early measure, the government restricted international flights' entry and restricted movements by imposing a nation-wide lockdown from 24 March, preceded by the Janta Curfew on 22 March 2020. About 21 million cases were counted in India by 11 August.

\section{Transmission of pandemics in urban settings}

McMichael \& McMichael (1993) used the term "crowd infections" to denote them by the outbreak of bacteria and viruses among a densely non-immune population in the urban settings. The consequences of 'imported' and 'exported' infected cases are massive in the travel industry and a country's medical sector (ibid). City life is more associated with mobility, inter-mixing, and risk-taking behavior, which eventually makes it vulnerable to transmissions compared to rural counterparts, especially in developing countries (Saker et al. 2004). SARS outbreak (2003) was transmitted to Hong Kong by a physician traveling from Guangdong, China, unchecked for symptoms due to an absence of border health controls (Abdullah et al. 2004). After the infection spread to his fellow lodgers, they carried the disease to their respective countries, thus starting the global SARS epidemic (ibid). The rapid spread of COVID-19 shows the potential threat that an infectious disease poses in a closely-knit world in the $21^{\text {st }}$ century. Dr. Michael Ryan, Executive Director, WHO Health Emergencies program, addressed the incidence of higher outbreaks in urban centres with improved travel networks of Europe and North America, compared to Africa at a virtual press conference (13 April 2020). He explained disease penetration from urban-centric core to the periphery with the movement of people, the distance, and social contact between individuals and the environment. He further added, there remained a possibility of weaker surveillance in rural areas, that might have under-detected the prevalence. An article published early March (2020) in Forbes reported rapid rise of community-level infections in all the larger metropolitans in the top ten globally most COVID-19 affected countries; China, UK, USA, South Korea, France, Germany, Iran, Spain, Switzerland, and Italy (Desai 2020). Common disruptive factors for the spread of pandemics in urban areas include higher population density, commutation through public transport, and high indoor-work-environments (Lee et al. 2020). Higher occupant density in built-up environments and increased indoor activity raise the human-to-human contact (Andrews et al. 2014; Dietz et al. 2020). A rapid in-migration results in more slums or housing shortages, leading to zoonotic outbreaks (Jones et al. 2008; Lee et al. 2020).

\section{Travel networks and pandemics}


With globalization, diseases cross geopolitical borders with human movements, termed explicitly as "mobility". Historical determinants associated with human mobility such as movements and behaviors, trade and commerce host susceptibility factors, and social inequality affected infectious diseases (Morens et al. 2004; Morens et al. 2008). Over administrative borders, regions differ in disease epidemiology, general health disparities and factors like poverty, education, housing, and nutrition and care (Mack et al. 2010). Epidemics like the plague in Athens (430-426 BC), Black Death in medieval Europe (1347-1350), Spanish flu (1918-1920) and AIDS pandemic across the African continent and then the world (from 1981 onwards) were transmitted along the trade routes (ibid, 2008). The influx of traders, businessmen, travelers, pilgrims, colonists, and soldiers etc. for centuries impacted on the spread of infections (Cartwright 1972; Curtin 1989). Written records mention that ill travelers were isolated as initial public health interventions before detection of the disease (Gushulak and MacPherson 2000). Most notably, the growing commercial aviation industry, international travel, and commerce aided to the rapid distribution of the pathogens of many deadly epidemics in the globalized world (IOM 2003). SARS (2002), drug-resistant malaria endemic to 92 countries (Martens and Hall 2000), Chikungunya in Italy (Rezza et al. 2007), and Swine Flu influenza (H1N1) (2009) were some of the recent global endemics. Ryan et al. (2002) carried out a selective review of a few specific illnesses often diagnosed in travellers from the developing regions. Estimates suggested that between 20 and 70 percent of the 50 million people reported some condition associated with their travel from the developed to the developing world each year (Steffen et al. 1987; Ryan and Kain 2000; Ryan et al. 2002). A study by Hufnagel et al. (2004) carried out simulations between local infection dynamics and individuals' traveling behavior by global aviation networks showed that by isolating around $2 \%$ of the largest cities, the outbreak of an epidemic be drastically reduced. A work by Kucharski et al. (2020) on transmission of COVID-19 ranging between 1.6 - 2.6 in Wuhan estimated that it almost declined to half with the introduction of travel control measures in the city. Using data of airport screenings of incoming passengers from abroad, a study in India (Mandal et al. 2020) predicted that there remained a high probability that every affected person can transmit the virus to 1.5 to 4 persons. The study also found out that the high-density cities of the country were worst affected.

\section{The rationale of the study}

An epidemic is a biological occurrence, but its transmission is driven by many socio-cultural factors, among which urbanization plays a crucial role. On one hand, it favours the development level, yet on the other, overcrowding in cities and human mobility networks provides a perfect setup for the spread of infections. This study focused on the transmission of COVID-19 and its outbreak pattern at the district level in India over time. Previous studies already took a predictive and curable approach to address the pandemic; however, we tried to understand the dynamics of transmission, which have gone unremarked in discussions. This study provided a detailed spatial analysis of the transmission and regional variations in India. We focused if the outbreak is urban-centric in nature or not. We emphasized the connectivity context that possibly has inflicted the transmission by considering the travel routes. Using the mode of transmission data for the available cases, we explained the diffusion of the virus among the population. Thus, the study tried to focus on questions like: What is the spatial pattern of COVID-19 transmission in India? Does the disease have an urban-centric character? What are the chief modes of transmission of the disease?

\section{Data And Methods}

In India, district-wise COVID-19 infection data was not coherently provided by any government agency at the national level; thus, we have relied on two non-government data sources https://www.howindialives.com and https://www.covid19india.org/. We availed the total number of reported pandemic cases from the first source from 22 March to 11 August 2020. The website collected data from different state government bulletins, the Indian Council of Medical Research (ICMR), and the Ministry of Health and Family Welfare (MoHFW) publications. The study considered districts as the spatial units of analysis. In 2020, there are more than 700 districts in India compared to 640 sections in the Census of India, 2011. Necessary adjustments equalized the numbers as in 2011. Percent of urban population was accessed from the Census of India, 2011. The month-wise international and domestic air passenger data by Airport Authority of India across 126 airports were availed from January to March 2020. Access to any real-time data on surface passenger flow (rail and road) was unavailable; thus, the road and rail density at district level was considered a proxy of surface mobility. To understand the spread of COVID-19, we classified the states and districts into higher urbanized and lower urbanized based on their level of urbanization and the national urbanization rate (31\% in 2011) (Table 2). Accordingly, 18 states and union territories were in the higher urbanized and 17 in the lower urbanized category. The districts in the individual categories were further sub-categorized following the same criteria. Thematic mapping explained the distribution of percent urban population in districts. Dot density maps were prepared (representative scale of 0.74 confirmed cases per million

population) for 22 March, $7^{\text {th }}$ and $21^{\text {st }}$ April, $5^{\text {th }}$ and $19^{\text {th }}$ May, 3 June, and 11 August (representative scale of 10 confirmed cases per million population) (Figure 1). Initially, a fifteen days time interval was maintained for the data to consider the incubation period of two weeks of the disease to show its first symptoms. Later we considered a two month gap in the data, to consider the effect of the effect of the unlock phase on the COVID cases.

Table 2: Districts reporting confirmed COVID-19 cases and percent of urban population. 


\begin{tabular}{|c|c|c|c|c|c|c|c|c|}
\hline \multirow[t]{3}{*}{ Date } & \multicolumn{4}{|c|}{ States with $31 \%$ and more urban population $(\mathrm{n}=18)$} & \multicolumn{4}{|c|}{ States with less than $31 \%$ urban population $(n=17)$} \\
\hline & \multicolumn{2}{|c|}{$\begin{array}{c}\text { Higher urbanized districts } \\
(\mathrm{n}=125)\end{array}$} & \multicolumn{2}{|c|}{$\begin{array}{c}\text { Lower urbanized districts (n } \\
=126)\end{array}$} & \multicolumn{2}{|c|}{$\begin{array}{l}\text { Higher urbanized districts } \\
(\mathrm{n}=57)\end{array}$} & \multicolumn{2}{|c|}{$\begin{array}{c}\text { Lower urbanized districts (n } \\
=332 \text { ) }\end{array}$} \\
\hline & Abs nos. & Percent & Abs nos. & Percent & Abs nos. & Percent & Abs nos. & Percent \\
\hline $\begin{array}{l}22-03- \\
2020\end{array}$ & 52 & 41.6 & 16 & 12.7 & 18 & 31.6 & 9 & 2.7 \\
\hline $\begin{array}{l}07-04- \\
2020 \\
\end{array}$ & 100 & 80 & 76 & 60.3 & 39 & 68.4 & 94 & 28.3 \\
\hline $\begin{array}{l}21-04- \\
2020\end{array}$ & 110 & 88 & 94 & 74.6 & 45 & 78.9 & 145 & 43.7 \\
\hline $\begin{array}{l}05-05- \\
2020\end{array}$ & 112 & 89.6 & 106 & 84.1 & 48 & 84.2 & 200 & 60.2 \\
\hline $\begin{array}{l}19-05- \\
2020 \\
\end{array}$ & 115 & 92 & 117 & 92.9 & 50 & 87.7 & 251 & 75.6 \\
\hline $\begin{array}{c}03-06- \\
2020 \\
\end{array}$ & 116 & 92.8 & 122 & 96.8 & 56 & 98.2 & 302 & 91 \\
\hline $\begin{array}{l}11-08- \\
2020\end{array}$ & 125 & 100 & 125 & 99.2 & 56 & 98.2 & 327 & 98.5 \\
\hline
\end{tabular}

Source: Census of India, 2011 and https://www.howindialives.com

Local Moran's I or LISA spatial autocorrelation technique generated cluster maps for the COVID-19 situation. It described how the observations at spatial locations are similar or dissimilar to their neighbours. Calculations were conducted for 22 March, 21 April, 19 May, 3 June, and 11 August 2020 at a 95 percent confidence level. Five scenarios distinguishing COVID-19 clusters in the country was observed with high-high (Hotspots), low-low (Coldspots), low-high (Spatial Outliers), high-low (Spatial Outliers), and no significant local autocorrelation values.

To understand the dynamics of the pandemic spread, we analyzed the modes of transmissions of this disease up to the first week of May. Information was collected from https://www.covid19india.org/ which provided information on transmission modes collected from the Centre and State publications, news bulletins and reports, social media platforms like Twitter, etc. We categorized them into six categories: namely travel(international and domestic), accidental exposure to a COVID-19 patient, family members of patients, frontline workers, and other reasons (Table 5). Information was available for every case until May; after which with the increase in the number of infections, the details lessened. Data was accessed between 22 March and 5 May 2020.

To explain the effect of urbanization and transport mediums on COVID-19 spread in India, first, we constructed three separate OLS models and then carried out a few tests to decide whether these models need to incorporate the spatial effect. The significant and positive test scores of Moran's I, Lagrange Multiplier Lag, Lagrange Multiplier Error, and Spatially Autoregressive Moving Average for all three models indicate the presence of spatial dependence in the data (Table 1). In general, there are two types of spatial dependence; first, the spatial error dependence which designates that the error terms across different spatial units are correlated (Anselin et al., 2006). Second, the spatial lag dependence, which specifies that the dependent variable in a particular region is affected by the independent variables in both that specific place and its neighbouring area. Here, the dependent variable was the COVID cases (11 August) and the independent variables were: hand washed with soap, having an internet connection, percentage of the urban population, rail per sq. km., road per sq. km., secondary level of education and above and hospital beds per hundred thousand population.After identifying the presence of spatial dependence, we re-estimated the OLS models with the maximum likelihood approach while controlling for spatial lag dependence. We considered spatial lag models instead of spatial error because of the assumption that dependency existed directly among the levels of the dependent variable (district wise COVID-19 cases); thus, the COVID cases at one location were affected by the COVID cases at the nearby locations. General form of the spatial lag model:

$Y=\rho W Y+X \beta+\varepsilon \ldots(1)$

where, $\mathrm{Y}$ is an $\mathrm{N} \times 1$ vector of observations of the dependent variable, $\mathrm{WY}$ is an $\mathrm{N} \times 1$ vector of spatial lag for the dependent variables, and $\rho$ is the spatial autoregressive coefficient. $X \beta$ is an $N \times K$ matrix of observation on the exogenous explanatory variables multiplied by a $K \times 1$ vector of regression coefficients $\beta$ for each $X$, and $\varepsilon$ is an $N \times 1$ vector of normally distributed random error terms. In the above equation, $\rho$ is a scalar parameter that indicates the effect of the dependent variable of the neighbouring regions on the dependent variable of a particular region.

Table 1: Diagnostic for spatial dependence.

\begin{tabular}{|l|l|l|l|}
\hline Test & MI/DF & Value & Probability \\
\hline Moran's I (error) & 0.21 & 8.61 & 0.00 \\
\hline Lagrange Multiplier (lag) & 1 & 56.63 & 0.00 \\
\hline Lagrange Multiplier (error) & 1 & 68.22 & 0.00 \\
\hline Lagrange Multiplier (SARMA) & 2 & 68.24 & 0.00 \\
\hline
\end{tabular}


For the multivariate models, the share of the households in a district with hand-washing practice using soap (hygiene practices) was estimated from the NSS $76^{\text {th }}$ Round data (2018), and the share of the households with internet connection (connectivity and mode of awareness) was calculated from NSS $75^{\text {th }}$ Round data (2017-18). The educational level and hospital bed per hundred thousand persons (medical infrastructure) were calculated from the Census of India 2011.

\section{Results}

\section{COVID-19 transmission in India}

In late March, the reported COVID-19 cases were concentrated sporadically in a few districts of Malappuram, Kasaragod of Kerala in the south, in and around Bengaluru (Karnataka), Mumbai (Maharashtra), Ahmedabad (Gujarat), New Delhi, a few districts of Punjab and Ladakh (Figure 1). The transmission rapidly spread from people with recent travel histories from abroad and international tourists. Religious gatherings like the events in Punjab and Delhi acted as virus spreaders among the population. According to the Health Ministry, a religious meeting in Delhi attributed to more than 4000 confirmed cases and at least 27 deaths across the country spreading as far as the Andaman and Nicobar Islands (PTI 2020; Dey 2020; Sharma 2020). An east-west divide aligned in the country in April. The transmission was lower in eastern India, where urbanization was less than 20 percent in most districts (2011) except in the million-plus city of Kolkata and surroundings. The southern districts of Kerala, Tamil Nadu, and Karnataka had a higher number of cases in April's first week. By month-end, the numbers had increased in districts of Maharashtra, Goa, Madhya Pradesh, in the western state of Gujarat, and stretched further to west Rajasthan, Delhi, Haryana, Punjab, and parts of Jammu and Kashmir including Ladakh. The concentration of infections in Delhi, Mumbai, Bengaluru, Ahmedabad, Indore, and Kolkata created hotspots. The government extended the lockdown to 30 May. By 19 May, there was a diffusion of active cases in rural districts of eastern India. Out migrating districts of Eastern Uttar Pradesh, Western Bihar, West Bengal, Jharkhand, and Orissa witnessed a migrant induced rise in infections. The hotspots continued to report active cases. With the first unlock phase from 1 June, there was a spike of infections across the country. The transport sector's functioning induced human movements from highly infected areas to villages and towns, further transmitting the virus. Since the index case, over 21 hundred thousand infections were reported by 11 August except for a few districts in Arunachal Pradesh, Mizoram, and Himachal Pradesh (Figure 2).

The uni-variate LISA score for 22 March of 0.10 indicated a low spatial autocorrelation of the disease in the districts (Figure 3). Hotspot clustering was in Delhi, Raigarh, Mumbai and Ahmednagar in Maharashtra, Rangareddy in Andhra Pradesh, Dakshin Kannada, Kasaragod, Kodagu, Kannur, Kozhikode and Alappuzha in Kerala and Bangalore Rural in Karnataka. Though coldspots were absent yet a heterogeneous scatter of high-low designated districts existed in this period. A month later, significant coldspots locations formed in the north-eastern and middle-eastern India. Hotspots of COVID-19 vanished from the south, newer districts around Bhilwara in Rajasthan, Ahmedabad in Gujarat, and Indore in Madhya Pradesh joined the list. Khorda in Odisha and Nagpur in Maharashtra had higher attribute values than their adjacent neighbours. Profound hotspots were observed in New Delhi, western Maharashtra around Mumbai, in eastern Tamil Nadu around Chennai and around Kolkata in West Bengal by 19 May. About 137 districts were in the low-low category. Over the next few months, the clustering of high-high districts became prolific in the earlier mentioned regions, and their numbers increased from 15 on 3 June to 25 on 11 August. However, New Delhi reported a decrease in the infected cases and dropped off this category. The coldspots extended to 119 districts, mainly in Jammu and Kashmir, Uttarakhand, Himachal Pradesh, Madhya Pradesh, and vast parts of north-eastern India.

\section{Urbanization and the spread of COVID-19}

Worldwide, the pattern of COVID-19 showed an initial concentration of confirmed cases in the cities, and India was no exception. The proportion of confirmed cases in 53 million-plus cities and 121 urban majority districts (40\% urban population) of India were plotted from 22 March to 11 August 2020 (Figure 4). On 22 March, among 401 registered cases, more than 70 percent were from districts with more than 40 percent of urban population, whereas 60 percent was from the million-plus cities. On 5 May, more than three-fourths of the infected cases belonged to the 121 higher urban districts. The million-plus cities attributed over 72 percent cases. Jamshedpur was the only million-plus city without reporting any single case. On 3 June, with relaxations in lockdown, India reported more than 207 thousand (MoHFW) cases, of which 67 percent were from million-plus cities. After almost two months, there was a considerable decrease in the share (44.7 percent); however, the total number of cases increased to more than 2.1 million patients.

On 22 March, about 41 percent of the higher urbanized districts reported COVID positive cases (Table 2). On 5 May this proportion increased to about 90 percent. There was an upsurge of patients within the lockdown period. About 60 percent of the lower urbanized districts reported infection. Threefourths of the lower urbanized districts and 115 higher urbanized districts reported cases on 19 May. With relaxations in human movements, there was a spike of infection in all categories. Unfavorable economic consequences alongwith the fear of contraction of the disease created a wave of return migrants comprising mainly the informal workers. About 91 percent of lower urbanized districts confirmed infection, while 0.8 percent increase occurred in higher urbanized districts. The transmission diffused to 122 lower urbanized districts of states with a high urban population and 56 of 57 higher urbanized districts of the lower urbanized states within a fortnight. By 11 August, the infection spread to all the country's higher urbanized areas, and less than ten districts reported had no COVID-19 case.

Districts in India's most urbanized states contributed to the maximum incidents since the beginning (Table 3). Mumbai, New Delhi, Hyderabad, and other million-plus cities primarily became the hotspots of the pandemic, confirming this virulent disease's urban character. The figures consistently rose

Page 5/14 
in all of these areas and contributed 70 percent of the infected cases $(48,129$ cases) by 5 May. Higher urbanized districts from the lower urbanized states like Jaipur, Indore, and Ranchi reported 16 percent of the total by the same period. Contrary to this, lower urbanized districts had less reporting. The number of cases crossed the first hundred thousand mark cumulatively in India by 19 May (MoHFW). With increasing human mobility, about 8.6 percent of the cases belonged to the lowest urbanized regions. Though the proportion is a meager to 71 percent as reported from the highly urbanized areas, yet it showed a 2 percent increase than earlier reported from these regions. A grave situation by 3 June was reflected in the less urbanized districts where it increased to 12.8 percent, a 4.2 percent increase within a fortnight. The reporting decreased 2 percent in the higher urbanized districts for the same duration. It further reduced by 11 August 2020; but a tremendous increase of 12 percent cases was reported from the lower urbanized districts in the country's higher urbanized states.

Table 3: Distribution of confirmed COVID-19 cases in districts of India according to percentage of urban population.

\begin{tabular}{|c|c|c|c|c|c|c|c|c|c|}
\hline \multirow[t]{3}{*}{ Date } & \multirow{3}{*}{$\begin{array}{l}\text { Total no. of } \\
\text { confirmed cases }\end{array}$} & \multicolumn{4}{|c|}{$\begin{array}{c}\text { States with } 31 \% \text { and more urban population }(\mathrm{n}= \\
18)\end{array}$} & \multicolumn{4}{|c|}{$\begin{array}{c}\text { States with less than } 31 \% \text { urban population }(n= \\
17)\end{array}$} \\
\hline & & \multicolumn{2}{|c|}{$\begin{array}{l}\text { Higher urbanized } \\
\text { districts }(\mathrm{n}=125)\end{array}$} & \multicolumn{2}{|c|}{$\begin{array}{l}\text { Lower urbanized } \\
\text { districts }(\mathrm{n}=126)\end{array}$} & \multicolumn{2}{|c|}{$\begin{array}{l}\text { Higher urbanized } \\
\text { districts }(\mathrm{n}=57)\end{array}$} & \multicolumn{2}{|c|}{$\begin{array}{l}\text { Lower urbanized } \\
\text { districts }(\mathrm{n}=332)\end{array}$} \\
\hline & & Abs nos. & Percent & Abs nos. & Percent & Abs nos. & Percent & Abs nos. & Percent \\
\hline $\begin{array}{l}22-03- \\
2020\end{array}$ & 401 & 263 & 65.6 & 48 & 12 & 62 & 15.5 & 28 & 7 \\
\hline $\begin{array}{l}07-04- \\
2020\end{array}$ & 5271 & 3220 & 61.1 & 762 & 14.5 & 857 & 16.3 & 432 & 8.2 \\
\hline $\begin{array}{l}21-04- \\
2020\end{array}$ & 19803 & 12655 & 63.9 & 1715 & 8.7 & 3821 & 19.3 & 1612 & 8.1 \\
\hline $\begin{array}{l}05-05- \\
2020\end{array}$ & 48129 & 33115 & 68.8 & 4112 & 8.5 & 7638 & 15.9 & 3264 & 6.8 \\
\hline $\begin{array}{c}19-05- \\
2020\end{array}$ & 99182 & 70456 & 71 & 7984 & 8.1 & 12188 & 12.3 & 8554 & 8.6 \\
\hline $\begin{array}{l}03-06- \\
2020\end{array}$ & 188947 & 130188 & 68.9 & 15541 & 8.2 & 19013 & 10.1 & 24205 & 12.8 \\
\hline $\begin{array}{l}11-08- \\
2020\end{array}$ & 2145427 & 1219011 & 56.8 & 433395 & 20.2 & 197533 & 9.2 & 295488 & 13.8 \\
\hline
\end{tabular}

\section{Source: Census of India, 2011 and https://www.howindialives.com}

\section{COVID-19 incidences and air travel}

The highly transmittable disease was brought into India by passengers returning from abroad. The first few cases had a travel history from Wuhan. The first fatality of the country was a man who had traveled from Saudi Arabia. Along with Indians returning from abroad, many cases came up among the international tourists (15 infected members of an Italian tourist group as reported on 4 March) (The Hindu Net Desk 2020). Air travel in India was discontinued from 22 March. About 45 percent of the initial concentration of infection was from districts with busiest international and domestic airports (Table 4). Districts with only domestic airports reported 14 percent of the total cases. The adjoining districts sharing common administrative boundaries with districts having airports reported 29 percent of the affected cases. Human mobility significantly inflicted the spread of the disease. With an increase in distance between the districts and the airports, the reporting subsequently lessened. After a fortnight with restrictions in air travel, there was a decline in infection in districts with both international and domestic airports (38.9\%) and only domestic airports (10.8\%). Considering the incubation period of two weeks of showing the first symptoms, more cases were reported from districts adjoining the airports (32.6\%) and other districts (17.8\%). Infection was reported across newer regions that initially had no cases by mid-April. In lockdown, air travel was restricted entirely except for the Indian government's special arrangements. However, the hotspots continued reporting a rise in the number of COVID patients daily. With the resumption in travel laws, about 54 percent of the cases came from districts having airports. Domestic air travel was relatively less till 3 June. Thus, this escalation in numbers was attributed to the air traffic and direct human-to-human contact by not adhering to the rules and precautions (The Hindu Net Desk 2020). A high percentage (28.9\%) of cases was reported from airport adjoining districts.

Table 4: Distribution of confirmed COVID-19 cases in districts of India according to their proximity near airports (international and domestic).

\begin{tabular}{|c|c|c|c|c|c|}
\hline Date & $\begin{array}{l}\text { Total no. of } \\
\text { COVID-19 } \\
\text { cases }\end{array}$ & $\begin{array}{l}\text { Percentage of cases in } \\
\text { districts with international } \\
\text { airports }\end{array}$ & $\begin{array}{l}\text { Percentage of cases in } \\
\text { districts with domestic } \\
\text { airports }\end{array}$ & $\begin{array}{c}\text { Percentage of cased in } \\
\text { adjoining districts of } \\
\text { airports }\end{array}$ & $\begin{array}{l}\text { Percentage of } \\
\text { cases in other } \\
\text { districts }\end{array}$ \\
\hline $\begin{array}{c}22- \\
03- \\
2020\end{array}$ & 401 & 45.1 & 13.5 & 29.2 & 12.2 \\
\hline $\begin{array}{c}07- \\
04- \\
2020\end{array}$ & 5271 & 38.9 & 10.8 & 32.6 & 17.8 \\
\hline
\end{tabular}

Source: https://www.howindialives.com and Airports Authority of India, 2020 
Since the reporting of the first COVID-19 case on 30 January in India, the disease spread substantially over the next few weeks. The national lockdown announced on 22 March was officially the last operational airflow day in the country. Fifteen days later, about 5,271 COVID-19 cases were confirmed. Though the proportion of infection amongst more than 1.3 billion population merely was a tiny percentage, the disease was clustered in cities and districts with a higher urbanization rate than the national average. The top ten metropolitans/districts in the number of infected cases contributed about 39 percent of the total with Mumbai alone, contributed to 12 percent (Table 5). Except for Kasaragod, other nine highest affected districts had airport terminals with an influx of travelers from abroad and within the country. In the Mumbai metropolitan region, both Mumbai and Thane districts were among the top ten infected areas similar to South Delhi and South-west Delhi in the NCR. Comparison with the city-wise cumulative air traffic handled, two of the busiest airport cities of India were among the top ten COVID affected regions, i.e., Mumbai and Delhi. The Indira Gandhi International Airport in Delhi shared 28 percent of the total international and 18 percent of the domestic air passengers from January to March 2020. The Chhatrapati Shivaji International Airport handled about 19 percent of the international traffic along with a 12 percent share of the total domestic airflow for the same duration. These ten cities are well connected with a high road network as $52 \mathrm{~km}$. per hundred sq. Km. in Indore and $26 \mathrm{~km}$. per hundred sq. Km. in Chennai and railway connectivity as $21 \mathrm{~km}$. per sq. Km. in Chennai and $19 \mathrm{~km}$. per hundred sq. Km. in Indore. A significant proportion of the disease's spread attributed to regions with good connectivity. On 7 April, about 63 percent of the total cases originated from five states; Maharashtra (19.4\%), Andhra Pradesh (13.3\%), Tamil Nadu (12.9\%), Delhi (10.7\%) and Kerala (6.4\%). Cumulatively they handled about 79 percent of the international airflow and 53 percent of the domestic air travel.

Table 5: Total COVID-19 cases on $7^{\text {th }}$ April, 2020 in cities/districts/states of India in descending order, air traffic (international and domestic) for January to March, 2020, percent of urban population, 2011 and road and rail network connectivity.

\begin{tabular}{|c|c|c|c|c|c|c|c|c|c|c|c|}
\hline \multirow[t]{2}{*}{ istrict/State } & \multicolumn{2}{|c|}{$\begin{array}{c}\text { Confirmed } \\
\text { COVID cases } \\
\text { on 7th April, } \\
2020 \\
\end{array}$} & \multicolumn{2}{|c|}{$\begin{array}{c}\text { International air } \\
\text { passengers (Jan + } \\
\text { Feb + Mar 2020) }\end{array}$} & \multicolumn{2}{|c|}{$\begin{array}{c}\text { Domestic air } \\
\text { passengers (Jan + } \\
\text { Feb + Mar 2020) }\end{array}$} & \multicolumn{2}{|c|}{$\begin{array}{c}\text { Total air passengers } \\
\text { (Jan + Feb + Mar } \\
2020)\end{array}$} & \multirow[t]{2}{*}{$\begin{array}{l}\text { Percentage } \\
\text { of urban } \\
\text { population }\end{array}$} & \multirow[t]{2}{*}{$\begin{array}{c}\text { Rail } \\
\text { network } \\
(\mathrm{km} / 100 \\
\text { sq. } \mathrm{km})\end{array}$} & \multirow[t]{2}{*}{$\begin{array}{c}\text { Road } \\
\text { network } \\
\text { (km/100 } \\
\text { sq. km) }\end{array}$} \\
\hline & $\begin{array}{l}\text { Abs. } \\
\text { nos. }\end{array}$ & Percent & Abs. nos. & Percent & Abs. nos. & Percent & Abs. nos. & Percent & & & \\
\hline Mumbai & 642 & 12.2 & $27,50,310^{\mathrm{a}}$ & 19.0 & $77,14,367$ & 12.1 & $1,04,64,677$ & 13.4 & 100 & 6.0 & 11.9 \\
\hline uth Delhi & 314 & 6 & $40,41,557^{\mathrm{b}}$ & 27.9 & $1,15,76,676$ & 18.1 & $1,56,18,233$ & 19.9 & 100 & 5.3 & 24.4 \\
\hline Indore & 171 & 3.2 & 8,023 & 0.1 & $7,35,576$ & 1.2 & $7,43,599$ & 0.9 & 72.7 & 18.9 & 51.6 \\
\hline tderabad & 171 & 3.2 & $8,11,771$ & 5.6 & $40,17,671$ & 6.3 & $48,29,442$ & 6.2 & 100 & 3.1 & 7.9 \\
\hline Pune & 159 & 3 & 33,932 & 0.2 & $18,30,574$ & 2.9 & $18,64,506$ & 2.4 & 61.7 & 2.0 & 8.8 \\
\hline isaragod & 158 & 3 & 0 & 0 & 0 & 0 & 0 & 0 & 39.2 & 3.7 & 14.6 \\
\hline hennai & 149 & 2.8 & $12,06,320$ & 8.3 & $37,79,250$ & 5.9 & $49,85,570$ & 6.4 & 100 & 20.9 & 25.9 \\
\hline Jaipur & 106 & 2 & $1,10,601$ & 0.8 & $10,94,019$ & 1.7 & $12,04,620$ & 1.5 & 53 & 3.4 & 9.5 \\
\hline Thane & 92 & 1.7 & $27,50,310^{\mathrm{a}}$ & 19.0 & $77,14,367$ & 12.1 & $1,04,64,677$ & 13.4 & 72.3 & 2.7 & 7.9 \\
\hline West Delhi & 86 & 1.6 & $40,41,557^{\mathrm{b}}$ & 27.9 & $1,15,76,676$ & 18.1 & $1,56,18,233$ & 19.9 & 79.2 & 2.5 & 19.3 \\
\hline $\begin{array}{l}\text { Top Ten } \\
\text { is/Districts }\end{array}$ & 2,048 & 38.9 & $89,62,514$ & 61.9 & $3,07,48,133$ & 48.2 & $3,97,10,647$ & 50.7 & 76.7 & $3.1^{c}$ & $10.0^{c}$ \\
\hline harashtra & 1024 & 19.4 & $28,02,614$ & 19.4 & $1,04,86,444$ & 16.4 & $1,32,89,058$ & 17.0 & 45.3 & 1.7 & 9.4 \\
\hline Ira Pradesh & 700 & 13.3 & $8,11,794$ & 5.6 & $51,55,136$ & 8.1 & $59,66,930$ & 7.6 & 32.9 & 1.7 & 11.2 \\
\hline mil Nadu & 682 & 12.9 & $16,09,859$ & 11.1 & $47,93,246$ & 7.5 & $64,03,105$ & 8.2 & 48.2 & 2.8 & 13.4 \\
\hline Delhi & 563 & 10.7 & $40,41,557$ & 27.9 & $1,15,76,676$ & 18.1 & $1,56,18,233$ & 19.9 & 95.7 & 7.8 & 21.7 \\
\hline Kerala & 338 & 6.4 & $21,70,095$ & 15.0 & $16,85,088$ & 2.6 & $38,55,183$ & 4.9 & 47.4 & 2.2 & 12.0 \\
\hline $\begin{array}{l}\text { ive states in } \\
\text { total }\end{array}$ & 3,307 & 62.7 & $1,14,35,919$ & 79.0 & $3,36,96,590$ & 52.8 & $4,51,32,509$ & 57.6 & 45.5 & $1.9^{c}$ & $10.9^{c}$ \\
\hline India & 5,271 & 100 & $1,44,78,686$ & 100 & $6,38,55,577$ & 100 & $7,83,34,324$ & 100 & 31.6 & $1.8^{\mathrm{c}}$ & $9.2^{\mathrm{C}}$ \\
\hline
\end{tabular}

${ }^{a}$ and ${ }^{b}$ implicate the same travellers as the same airports cover both the districts

$c$ denotes the mean value e: https://www.howindialives.com; Airports Authority of India, 2020; Census of India, 2011 and www.divag/gdata

\section{Modes of transmission of COVID-19 in India}

For the transmission of the infection, the humans acted as vectors. On 22 March, most of the cases were reported due to travel, more specifically international air travel (67.3\%). Family members of patients (16.5\%) were infected next with the disease (Table 6). With the restrictions in air travel, the transmission through international travel lessened (16.9\%). However, domestic travel still contributed to the maximum spread (52.9\%). Accidental exposure to infected individuals (15.1\%) due to lack of awareness increased transmission in the interval, 23 March and 8 April. It contributed to almost 65 percent of the transmission between 8 April and 5 May. International air travel contributed to almost 12 percent and 22 percent in the higher and lowers urbanized districts on 5 May. Domestic travel had a higher share, of nearly 41 percent and 32 percent in these two categories. Accidental exposure to infected individuals in places of gathering attributed quite a high percentage in the spread of the epidemic (34.6\% and $28.5 \%$, respectively). With the insurgence of outbreaks amongst a larger population, the transmission details became challenging to collect. 
Table 6: Modes of transmission (as reported) of COVID-19 cases in India, $22^{\text {nd }}$ March $2020-5^{\text {th }}$ May, 2020

\begin{tabular}{|c|c|c|c|c|c|c|c|c|c|c|c|c|c|c|}
\hline \multirow{3}{*}{\multicolumn{2}{|c|}{ Mode of Transmission }} & \multicolumn{4}{|c|}{ Travel histories } & \multirow{2}{*}{\multicolumn{2}{|c|}{$\begin{array}{l}\text { Exposed to any } \\
\text { COVID-19 infected } \\
\text { patient randomly }\end{array}$}} & \multirow{2}{*}{\multicolumn{2}{|c|}{$\begin{array}{c}\text { Family } \\
\text { members of } \\
\text { COVID-19 } \\
\text { patient }\end{array}$}} & \multirow{2}{*}{\multicolumn{2}{|c|}{$\begin{array}{c}\text { Frontline } \\
\text { workers on- } \\
\text { duty exposure }\end{array}$}} & \multirow{2}{*}{\multicolumn{2}{|c|}{$\begin{array}{l}\text { Other } \\
\text { reasons }\end{array}$}} & \multirow{3}{*}{$\begin{array}{l}\text { Total } \\
\text { Cases }\end{array}$} \\
\hline & & \multicolumn{2}{|c|}{$\begin{array}{l}\text { International } \\
\text { trip }\end{array}$} & \multicolumn{2}{|c|}{ Domestic trip } & & & & & & & & & \\
\hline & & $\begin{array}{l}\text { Abs } \\
\text { nos. }\end{array}$ & Percent & $\begin{array}{l}\text { Abs } \\
\text { nos. }\end{array}$ & Percent & $\begin{array}{l}\text { Abs } \\
\text { nos. }\end{array}$ & Percent & $\begin{array}{l}\text { Abs } \\
\text { nos. }\end{array}$ & Percent & $\begin{array}{l}\text { Abs } \\
\text { nos. }\end{array}$ & Percent & $\begin{array}{l}\text { Abs } \\
\text { nos. }\end{array}$ & Percent & \\
\hline $\begin{array}{l}\text { Till } 22^{\text {nd }} \\
\text { March }\end{array}$ & Total & 237 & 67.3 & 4 & 1.1 & 35 & 9.9 & 58 & 16.5 & 16 & 4.5 & 2 & 0.6 & 352 \\
\hline $\begin{array}{c}23^{\text {rd }} \\
\text { March - } \\
7^{\text {th }} \text { April }\end{array}$ & Total & 292 & 16.9 & 913 & 52.9 & 261 & 15.1 & 124 & 7.2 & 39 & 2.3 & 96 & 5.6 & 1725 \\
\hline $\begin{array}{c}8^{\text {th }} \text { April } \\
-5^{\text {th }} \\
\text { May }\end{array}$ & Total & 45 & 4.8 & 130 & 13.7 & 619 & 65.4 & 69 & 7.3 & 68 & 7.2 & 16 & 1.7 & 947 \\
\hline $5^{\text {th }}$ May & $\begin{array}{l}\text { Higher } \\
\text { urbanized } \\
\text { districts }\end{array}$ & 102 & 11.8 & 353 & 40.7 & 300 & 34.6 & 82 & 9.4 & 24 & 2.8 & 7 & 0.8 & 868 \\
\hline & $\begin{array}{c}\text { Lower } \\
\text { urbanized } \\
\text { districts }\end{array}$ & 472 & 21.9 & 694 & 32.2 & 615 & 28.5 & 169 & 7.8 & 99 & 4.6 & 107 & 5.0 & 2156 \\
\hline & Total & 574 & 19.0 & 1047 & 34.6 & 915 & 30.3 & 251 & 8.3 & 123 & 4.1 & 114 & 3.8 & 3024 \\
\hline
\end{tabular}

\section{Source: https://www.covid19.org}

\section{Effects of urbanization and transit mediums on the pandemic}

The incidents of COVID-19 in India followed a clear spatial clustering at the district level. Districts contiguous to each other had similar incidents of COVID-19 cases. At the beginning of the pandemic, metropolitan and higher urbanised districts had a higher share of infections. Districts with airports reported higher incidence of cases till April. Thus, we constructed three separate sets of OLS models and their spatial lag variants to understand the effects of urbanisation and transit mediums on the spread of the pandemic (Table 7). The dependent variable for these models was COVID19 cases per million population in the districts of India.

Table 7: Effects of urbanization and transit mediums on the spatial spread of COVID-19

\begin{tabular}{|c|c|c|c|c|c|c|}
\hline Variables & $\begin{array}{l}\text { Model IA } \\
\text { (OLS) }\end{array}$ & $\begin{array}{c}\text { Model IB } \\
\text { (Spatial Lag) } \\
\end{array}$ & $\begin{array}{c}\text { Model IIA } \\
\text { (OLS) }\end{array}$ & $\begin{array}{c}\text { Model IIB } \\
\text { (Spatial Lag) } \\
\end{array}$ & $\begin{array}{l}\text { Model IIIA } \\
\text { (OLS) }\end{array}$ & $\begin{array}{c}\text { Model IIIB } \\
\text { (Spatial Lag) } \\
\end{array}$ \\
\hline & Coefficient & Coefficient & Coefficient & Coefficient & Coefficient & Coefficient \\
\hline Percent urban population & $5.06 * * *$ & $4.37 * * *$ & & & $3.35 * * *$ & $2.5^{*}$ \\
\hline Rail line per 100 sq. Km. & & & $1285.1 * * *$ & $1301.3^{* * *}$ & 592.6 & $857.65^{* *}$ \\
\hline Road per 100 sq. Km. & & & $534.04^{* *}$ & $459.08^{* *}$ & -146.19 & -83.82 \\
\hline Airport & & & $159.08 * * *$ & $152.74^{* * *}$ & $54.49 * *$ & $69.81 * * *$ \\
\hline $\begin{array}{l}\text { Hand-washing with soap (\% of } \\
\text { households) }\end{array}$ & & & & & $-0.71 * *$ & $-0.61 * *$ \\
\hline $\begin{array}{l}\text { Availability of Internet (\% of } \\
\text { households) }\end{array}$ & & & & & $-1.93 * * *$ & $-1.67 * * *$ \\
\hline Secondary and above education (\%) & & & & & $4.25^{*}$ & $3.05^{* *}$ \\
\hline $\begin{array}{l}\text { Hospital beds per hundred } \\
\text { thousand population }\end{array}$ & & & & & $0.59 *$ & $0.64 * * *$ \\
\hline Rho & - & $0.37 * * *$ & - & $0.46^{* * *}$ & - & $0.39 * * *$ \\
\hline Constant & 1.24 & -26.5 & 23.03 & -25.94 & -44.04 & -62.39 \\
\hline Number of observations & 640 & 640 & 640 & 640 & 640 & 640 \\
\hline Number of variables & 1 & 1 & 3 & 3 & 8 & 8 \\
\hline R squared & 0.18 & 0.27 & 0.11 & 0.27 & 0.25 & 0.33 \\
\hline Adjusted R-squared & 0.18 & & 0.11 & & 0.24 & \\
\hline Log likelihood & -4359.91 & -4334.78 & -4386.42 & -4345.77 & -4334.65 & -4304.39 \\
\hline Akaike info criterion & 8723.83 & 8675.56 & 8780.83 & 8701.54 & 8727.45 & 8632.78 \\
\hline $\begin{array}{l}\text { Note: }{ }^{* * *} \text { and }{ }^{* *} \text { denote signifi } \\
\text { significance respectively }\end{array}$ & 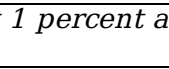 & percent 1 & & & & \\
\hline
\end{tabular}

Significant and positive values of Rho across all of the spatial lag models indicated the inherent spatial dependence in COVID-19 transmission, measuring the average influence on each district by their neighbouring districts. As a result, compared to their OLS variants, the overall model fit improved, as indicated by higher values of R-square and smaller values of Akaike info Criterion. When compared with the effect of the covariates between OLS models and their spatial lag variants, the effect of other covariates has remained almost the same, except for the road per hundred sq. $\mathrm{Km}$. between Model IIA and IIIB.

Model IB illustrated the effects of only urbanisation on the spread of the pandemic while controlling the spatial effect. This model showed that urbanisation had a significant positive association with the number of infections. Also, the spatial interaction term (Rho) was significantly positive, 
implying the crucial role of spatial contiguity in the spread of this disease to the neighbouring districts. Model IIB examined only the effects of transit mediums along with the spatial interaction term. The spatial interaction term, Rho and the three transit mediums were jointly in positive association with the spread of the pandemic. Model IIIB was the complete model where the effects of urbanisation and transit mediums were calculated after controlling all other relevant covariates. Urbanisation still was positively associated with COVID-19 cases at 1 per cent level of significance. Rail line density and presence of an airport in a district also significantly positively associated with infected cases. As the lockdown eased, migrants fled from the cities to their rural homes across the country.

Practice of hand-washing with soap was used as a proxy for better hygiene condition which showed a significant negative relation to the spread of the pandemic. As recommended by WHO (2020), maintenance of good personal hygiene especially washing hands regularly protects us against contagious infections. The Government of India extensively tried to create awareness during this crisis through printed, visual and audio media. Internet availability at the household level was used as a proxy of exposure to media which again showed a negative relationship with total infections. This revealed that media exposure played a significant role in curbing the transmission. Spreading awareness and message briefs about maintaining good personal hygiene, abiding strict lockdown rules, maintaining adequate social distancing in public places, following government guidelines, Aarogya Setu application download was possible through internet connectivity. However, poor connectivity in rural areas or lack of facilities at home (Ganguly et al. 2020) posed difficulty in remote areas. Higher educated population implied a better quality of human capital concentration and more hospital beds per hundred thousand people was positively associated with COVID-19 cases. These factors may be related to each other as people in urban areas often are more educated and medical infrastructure remains better in cities than villages.

\section{Discussion}

Despite all the research on the predictive factors, health-seeking behavior, effects of lockdown, or estimating the outbreak's epidemiology, very few papers aimed to understand the underlying factors of diffusion of the pandemic. The transmission showed a familiar pattern of emergence, initially urban-centric, and then to other parts in India. Metropolitan centres contributed three-fourths of total cases from the beginning. Excellent connectivity, density, informal housing, etc. played significant roles in this transmission. Mumbai's financial capital, the administrative capital of New Delhi, the southern districts of Kerala, Tamil Nadu, Karnataka, and Andhra Pradesh became the hotspots. Identification of the travel routes for human movements directly impacted the infections in the cities, especially by air travel. Government requested to refrain travel to China and issued quarantine to passengers with a travel history from China on 6 February (WHO 2020). Commutation to work being a regular urban phenomenon was a primary concern for the virus's potency to spread to the entire population quickly (Desai 2020). Our findings show that over 60 percent of the total COVID positive cases reported from the million-plus cities increased to more than 72 percent on 19 May and later lowered to 45 percent on 11 August. The highly urbanized districts continued to amplify their numbers. The problem with cities is that they create ecosystems of their own, with higher temperatures and less seasonal changes than their surroundings (Bradley and Altizer 2007; Shochat et al. 2006). As a result, the extent of the zoonotic diseases is prolonged, and the transmission is extended (Lindahl and Grace 2015). Home isolation, social distancing, or testing everyone was challenging for highly populated slums like Dharavi in Mumbai, where about eight hundred thousand people live in 2.1 sq. km. (Gupta 2020). A negative correlation existed between the regional variation of COVID cases and hygiene practices like washing hands with soap and having internet connections and roads per hundred sq. $\mathrm{Km}$. Lesser transport options led to a lower incidence of the spread of the infection, and post lockdown the burden of the cases in the urban hotspots lowered. With the regeneration of rail connectivity, there was an increase in transmission even in rural districts. Singh et al. (2020) briefed about 4,150 Shramik trains operated and lowered the transportation crisis in this period for 55 lakh labourers. About half of them originated from Gujarat, Maharashtra and Punjab and travelled to Uttar Pradesh, Bihar, Jharkhand, Odisha, Madhya Pradesh, Rajasthan and West Bengal (ibid). This return migration caused a surge in the COVID-19 cases in the rural districts as the first unlock period started from June. The shutdown of all employment sectors and no wages observed an exodus of informal workers from more prominent urban centres to their native places in the less urbanized areas. As a result, by 19 May, about 75 percent of the rural majority districts started reporting infections. The concern remained for community transmission to villages and small towns that lacked health management infrastructure to face the alarming situation.

Regardless of the findings, our study has several limitations. First, the data quality may have significantly affected our inferences. We used published COVID-19 data from two sources, which had their shortcomings, mainly because of no homogeneous reporting. The outcome of every infection was unavailable, especially in the later phase. Secondly, the lack of historical data of passengers' location by the road and rail route made it impossible to create the network of the monthly traffic network and predict transmission routes. Lastly, we did not consider other vital factors like the presence of comorbidities, quality of care received, and other demographic factors like the age or sex distribution of the confirmed cases for the study.

\section{Conclusion}

The transmission of COVID-19 in India confirmed its initial urban-centric character. In the pre-lockdown and the post-lockdown stages, the functioning of the transport networks attributed significantly in transmitting the virus from the high urban containment zones. Later, there was a gradual shift of infections from urban to rural areas; however, the number of cases kept increasing in the former. The massive reverse migration after lockdown spiked the infected cases. In India, where socio-economic issues like homelessness, daily wage payments, unemployment, and lack of social security pre-exist; the nation-wide lockdown's inadequate planning also deteriorated the condition. Disorganized connectivity created a complete chaos, and financial insecurity of the informal workers forced them to walk their way back, many losing lives because of over-exhaustion and hunger. India's chief concern in the time of pandemic continues to be high population; ill-equipped public health system and insufficient resources to provide medical care for all. 
Suggesting an action plan that can curb the pandemic is impossible from the paper's elementary observations. Measurements to stop the spread at the original location must have been taken. In contrast, knowledge about the disease should have been passed on to the global community and health workers (Neiderud 2015) at the initial stage. The introduction of policies to relax the lockdown in cities strategically and gradually (Telles 2020) with additional new physical distancing methods is essential. Strategies like the Bhilwara model (Rajasthan)he Kerala model, and the Dharavi model (Mumbai) against the transmission were efficient in different time intervals. Investments strengthening health infrastructure are essential. Rural-tourban migration is inevitable; thus, living conditions should be improved in the cities through policy interventions.

In conclusion, we say that the COVID-19 situation exposed different shortcomings in managing the proper functioning of the country. On the one hand, adverse human interventions on the environment might have led to the initial occurrence of the pandemic, yet the impact of socio-economic factors like poverty played much more if not an equal role in its spread. Challenges in city planning should be addressed instead of encouraging unprecedented urban growth. Preparedness to restrict infectious diseases at the community levels is better than the task of finding a cure for life-threatening pandemics after their spread. Disease control and monitoring, especially for the infectious diseases, should be a multi-disciplinary approach that must include social and environmental values along with the science of medicine and epidemiology.

\section{Declarations}

\section{Compliance with Ethical Standards:}

The authors declare that there was no potential conflicts of interest while conducting the research or preparing the manuscript. No research grant was obtained from funding agencies to prepare this manuscript. This study has been carried out using secondary data and did not involve any human participants or animals. All the data are available in the public domain thus, no Informed consent was required.

\section{Availability of data and material:}

This study is based on secondary data sources of Census of India (https://censusindia.gov.in/), 2011, NSS $75^{\text {th }} \& 76^{\text {th }}$ rounds (http://www.mospi.gov.in/) and two non-government data sources namely, https://www.howindialives.com and https://www.covid19india.org/ which are all available in the public domain for free of cost. No ethical clearance was required for the utilization of the datasets.

Code Availability: Not applicable

\section{Authors' contributions:}

All authors contributed to the study conception, design and visualization. Material preparation, data collection and analysis were performed by Devarupa Gupta, Dibyendu Biswas and Pintu Kabiraj. The first draft was written by Devarupa Gupta and Dibyendu Biswas commented on this version of the manuscript. All authors read and approved the final manuscript.

\section{References}

Abdullah, A. S. M., Thomas, G. N., McGhee, S. M., \&Morisky, D. E. (2004). Impact of severe acute respiratory syndrome (SARS) on travel and population mobility: implications for travel medicine practitioners. Journal of travel medicine, 11(2), 107-111.

Andrews, J.R., Morrow, C., Walensky, R.P., \& Wood, R. (2014). Integrating social contact and environmental data in evaluating tuberculosis transmission in a South African township. The journal of infectious diseases, 210(4), 597-603. DOI: https://doi.org/10.1093/infdis/jiu138.

Anselin, L., Syabri, I., \& Kho, Y. (2006). GeoDa: An Introduction to Spatial Data Analysis. Geographical Analysis, 38(1), 5-22.

Bradley, C. A., \& Altizer, S. (2007). Urbanization and the ecology of wildlife diseases. Trends in ecology \& evolution, 22(2), 95-102.

Cartwright, F.F. \& Biddiss, M.D. (1972). Disease and history. Crowell.

Census of India. (2011). Census of India 2011 Provisional Population Totals. New Delhi: Office of the Registrar General and Census Commissioner.

Curtin, P. D. (1989). Death by Migration: Europe's Encounter with the Tropical World in the $19^{\text {th }}$ century. Cambridge University Press.

Desai, D. (2020). Urban Densities and the Covid-19 Pandemic: upending the sustainability myth of global megacities. Observer Research Foundation (ORF) Occasional Paper, 244(4).

Dey, S. (19 April 2020). 30\% of cases across India tied to Jamaat event: Govt. The Times of India. Retrieved from https://timesofindia.indiatimes.com/india/corona-cases-in-india-30-of-cases-across-india-tied-to-jamaat-event/articleshow/75227980.cms.

Ganguly, D., Misra, S., \&Goli, S. (2020). India's COVID-19 Episode: Resilience, Response. Impact and lessons.

Gupta, S. (25 April 2020). Coronavirus: Mumbai's Dharavi, A COVID-19 Hotspot, Reports Sharp Drop In New Cases, ndtv.com. Retrieved from https://www.ndtv.com/mumbai-news/coronavirus-mumbaisdharavi-a-covid-19-hotspot-reports-sharp-drop-in-new-cases-2217864.

Page $10 / 14$ 
Gushulak, B. D., and MacPherson, D. W. (2000). Population mobility and infectious diseases: the diminishing impact of classical infectious diseases and new approaches for the 21st century. Clinical infectious diseases, 31(3), 776-780.

Hufnagel, L., Brockmann, D., \& Geisel, T. (2004). Forecast and control of epidemics in a globalized world. Proceedings of the national academy of sciences, 101(42), 15124-15129.

International Organization for Migration (IOM). (2003). World migration report: managing migration - challenges and responses for people on the move.

Jones, K. E., Patel, N. G., Levy, M. A., Storeygard, A., Balk, D., Gittleman, J. L., \& Daszak, P. (2008). Global trends in emerging infectious diseases. Nature, 451(7181), 990-993.

Kucharski, A. J., Russell, T. W., Diamond, C., Liu, Y., Edmunds, J., Funk, S., Eggo, R. M., Sun, F., Jit, M., Munday, J. D. \& Davies, N. (2020). Early dynamics of transmission and control of COVID-19: a mathematical modelling study. The lancet infectious diseases. 20(5), 553-558. DOI: https://doi.org/10.1016/S1473-3099(20)30144-4.

Lee, V. J., Ho, M., Kai, C. W., Aguilera, X., Heymann, D., \& Wilder-Smith, A. (2020). Epidemic preparedness in urban settings: new challenges and opportunities. The lancet infectious diseases, 20(5), 527-529.

Lindahl, J. F., \& Grace, D. (2015). The consequences of human actions on risks for infectious diseases: a review. Infection ecology \& epidemiology, 5(1), DOI: https://doi.org/10.3402/iee.v5.30048.

Mack, A., Choffnes, E. R., \&Relman, D. A. (Eds.). (2010). Infectious disease movement in a borderless world: workshop summary. National Academies Press.

Mandal, S., Bhatnagar, T., Arinaminpathy, N., Agarwal, A., Chowdhury, A., Murhekar, M., ... \& Sarkar, S. (2020). Prudent public health intervention strategies to control the coronavirus disease 2019 transmission in India: A mathematical model-based approach. The Indian journal of medical research, 151(2-3), 190. DOI: https://www.ncbi.nlm.nih.gov/pubmed/32202261.

Martens, P., \& Hall, L. (2000). Malaria on the move: human population movement and malaria transmission. Emerging infectious diseases, 6(2), 103109. DOI: https://doi.org/10.3201/eid0602.000202.

McMichael, A. J., \& McMichael, T. (1993). Planetary overload: global environmental change and the health of the human species. Cambridge University Press.

Morens, D. M., Folkers, G. K., \& Fauci, A. S. (2008). Emerging infections: a perpetual challenge. The lancet infectious diseases, 8(11), 710-719.

Morens, D. M., Folkers, G. K., \& Fauci, A. S. (2004). The challenge of emerging and re-emerging infectious diseases. Nature, 430(6996), $242-249$.

Myers, S. S. \& Patz, J. A. (2009). Emerging threats to human health from global environmental change. Annual review of environment and resources, 34 , 223-252.

Neiderud, C. J. (2015). How urbanization affects the epidemiology of emerging infectious diseases. Infection ecology \& epidemiology, 5(1), 1-9, DOI: https://doi.org/10.3402/iee.v5.27060.

Press Trust of India (PTI). (18 April, 2020). Coronavirus: Nearly 4,300 cases were linked to Tablighi Jamaat event, says Health Ministry. The Hindu. Retrieved from https://www.thehindu.com/news/national/coronavirus-nearly-4300-cases-were-linked-to-tablighi-jamaat-event-says-healthministry/article31376202.ece.

Rezza, G., Nicoletti, L., Angelini, R., Romi, R., Finarelli, A.C., Panning, M., Cordioli, P., Fortuna, C., Boros, S., Magurano, F., Silvi, G., Angelini, P., Dottori, M., Ciufolini, M.G., Majori, G.C., Cassone, A. \& CHIKV Study Group. (2007). Infection with chikungunya virus in Italy: an outbreak in a temperate region. Lancet 370(9602), 1840-1846.

Ryan, E. T., Wilson, M. E. and Kain, K. C. (2002). Illness after International Travel. The New England journal of medicine, 347(7), 505-516.

Ryan, E. T., Kain, K. C. (2000). Health advice and immunizations for travelers. The New England journal of medicine, 342(23), $1716-1725$.

Saker, L., Lee, K., Cannito, B., Gilmore, A., \& Campbell-Lendrum, D. H. (2004). Globalization and infectious diseases: a review of the linkages (No. TDR/STR/SEB/ST/04.2). World Health Organization.

Sharma, N. C. (18 April, 2020). 30\% covid-19 cases in India linked to Tablighi Jamaat event: Govt. Livemint. Retrieved from https://www.livemint.com/news/india/30-covid-19-cases-in-india-linked-to-tablighi-jamaat-event-govt-11587218560611.html. 
Shochat, E., Warren, P. S., Faeth, S. H., Mclntyre, N. E., \& Hope, D. (2006). From patterns to emerging processes in mechanistic urban ecology. Trends in ecology \& evolution, 21(4), 186-191.

Singh, S. K., Patel, V., Chaudhary, A., \& Mishra, N. (2020). Reverse migration of labourers amidst COVID-19. Economic \& political weekly, 55(32-33), 2529.

Steffen, R., Rickenbach, M., Wilhelm, U., Helminger, A., Schar, M. (1987). Health problems after travel to developing countries. The journal of infectious diseases, 156, 84-91.

Telles, C. R. (2020). Covid-19: A brief overview of virus social transmission through atmosphere. Preprint. MediArXiv. DOI: https://doi. org/10.33767/osf. io/2hek4.

The Hindu Net Desk. (30June, 2020). Coronavirus India: Day 98 updates. The Hindu. Retrieved from https://www.thehindu.com/news/national/indiacoronavirus-lockdown-june-30-2020-live-updates/article31950742.ece.

United Nations, Department of Economic and Social Affairs, Population Division (2018). The world's cities in 2018 - Data Booklet.

World Health Organization (WHO). (6 February, 2020). Novel Coronavirus (2019-nCoV) Situation Report - 2. Retrieved from https://www.who.int/docs/default-source/wrindia/india-situation-report-2.pdf?sfvrsn=962f294b_0.

\section{Figures}

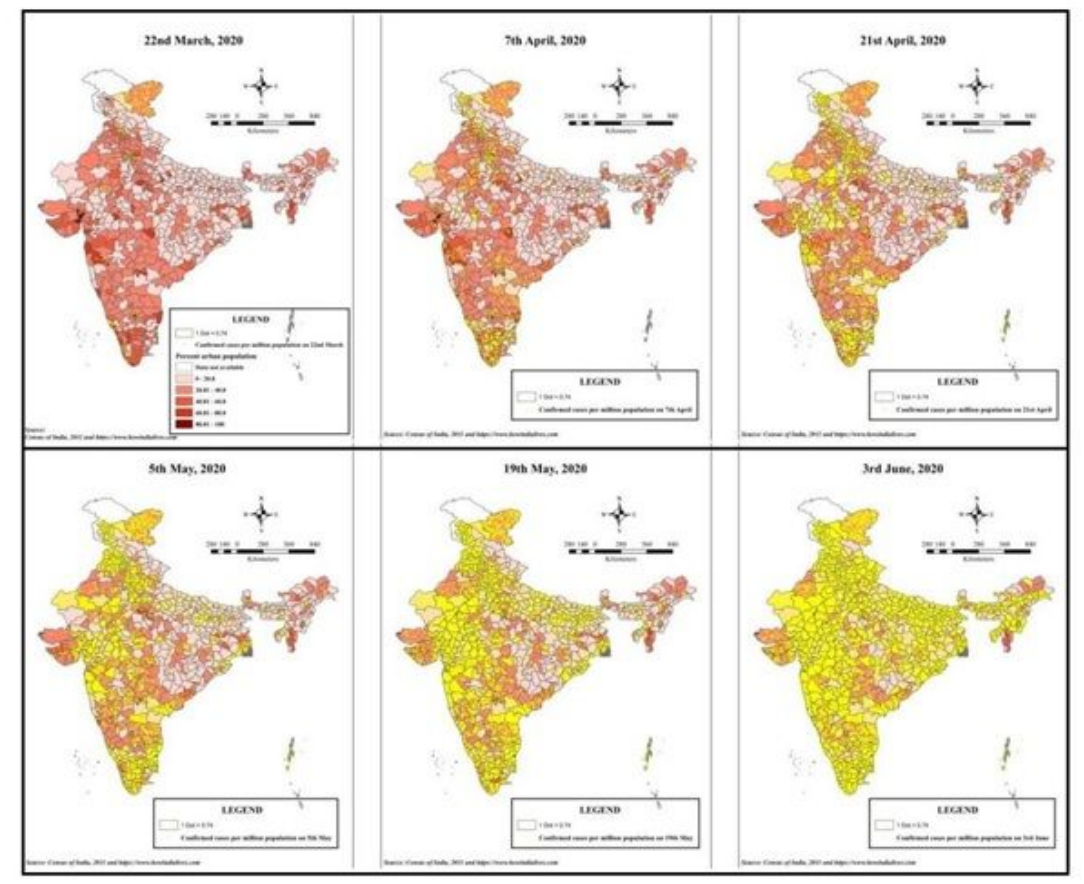

\section{Figure 1}

Percent of urban population and confirmed Covid-19 cases day-wise district level India (March - June 2020) 


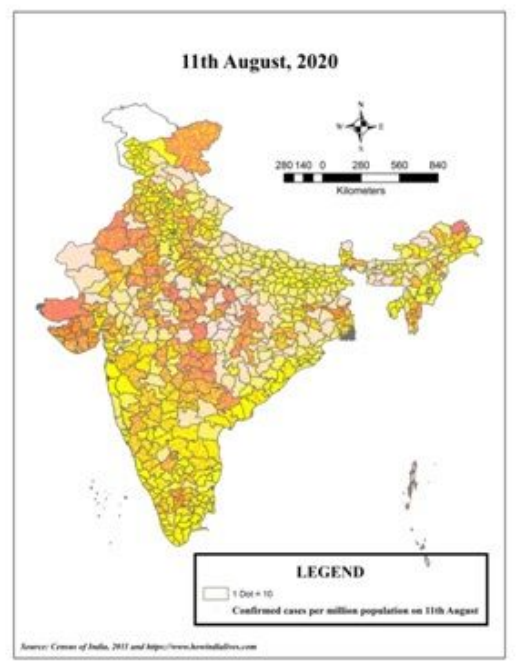

Figure 2

Percent of urban population and confirmed Covid-19 cases day-wise district level India on 11th August 2020
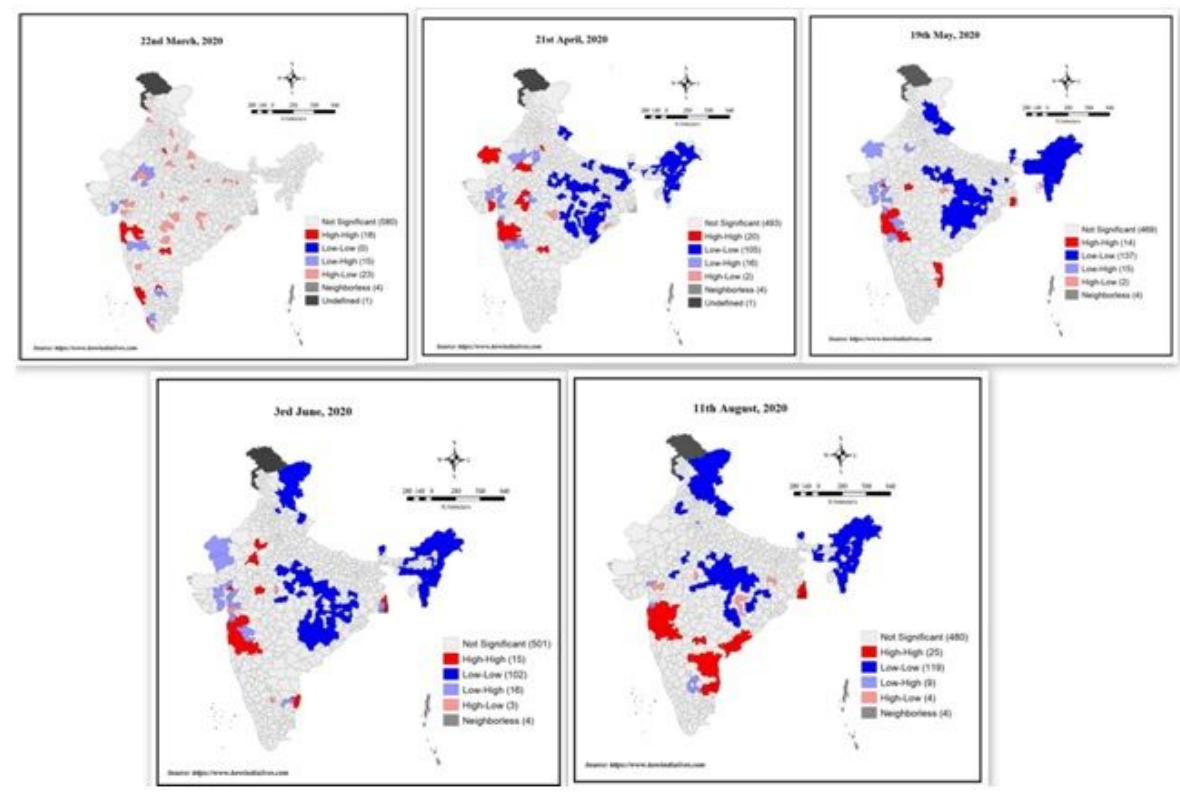

Figure 3

Univariate LISA maps exploring COVID-19 clusters across districts of India for 22nd March, 21st April, 19th May, 3rd June and 11th August 2020

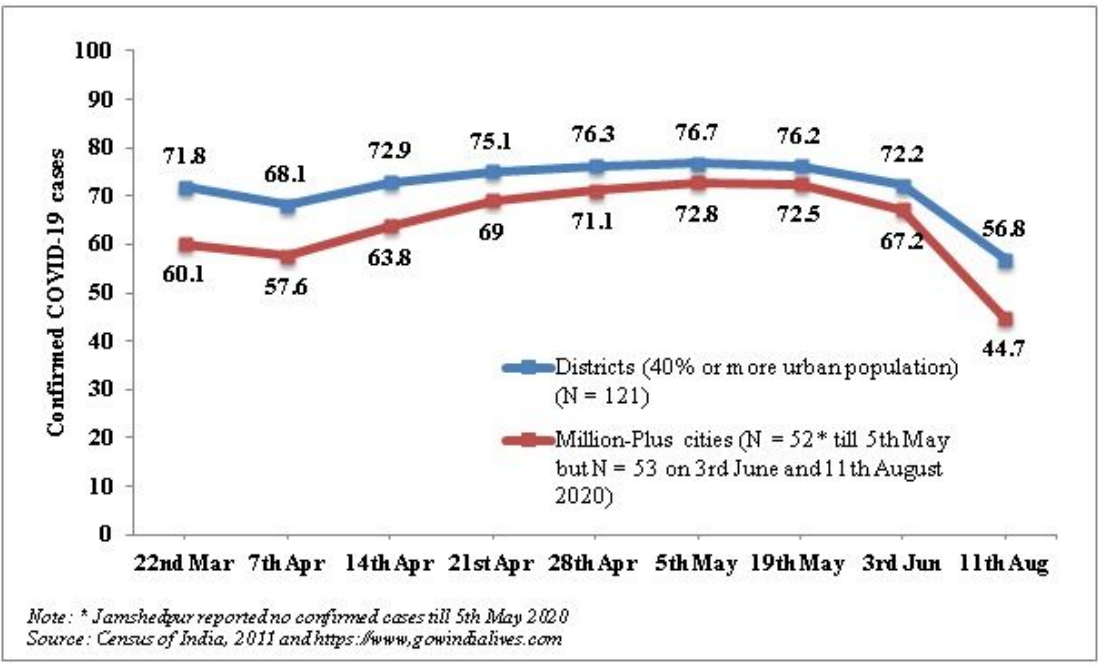


Figure 4

Percentage of reported confirmed COVID-19 cases in urban areas India (March - June 2020)

Page $14 / 14$ 